\title{
Pendidikan Nikah di Masa Pandemi Menurut Kh. Muhammad Kholil Bangkalan
}

\author{
Asep Awaluddin \\ STAIMAS Wonogiri \\ Asepawaluddin9@gmail.com
}

\begin{abstract}
Abstrak
Nikah adalah kebutuhan dasar manusia dewasa. Terdapat permasalahan yang sering terjadi dalam pernikahan, terlebih lagi apabila pernikahan tersebut adalah pernikahan dini di masa pandemi. Pernikahan antara laki-laki dan perempuan yang usia mereka di bawah batas usia menikah berdasarkan aturan perundangan-undangan dan atau pernikahan yang belum memiliki syarat-syarat yang lengkap. Agama Islam menjaga kehormatan manusia, sekaligus mengatur pembibitan generasi yang berkualitas, berakahlak mulia dan bernasab yang jelas dengan pernikahan. Penelitian ini adalah penelitian kualitatif deskriptif, adapun metode pengumpulan data berbasis kepustakaan, wawancara dan pengamatan langsung di lapangan. Proses ini bermula dari pernikahan. Bangunan rumah tangga yang sakinah, mawaddah wa rahmah akan dicapai bila pengetahuan tentang nikah ini tidak terlambat diperoleh dan para calon mempelai, sehingga para calon pasangan baik laki-laki dan perempuan telah mempersiapkannya. Pendidikan nikah menurut KH. Muhammad Kholil Bangkalan adalah diberikan pada pendidikan tingkat dasar terlebih saat pendidikan memanfaatkan jaringan Internet dalam Pembelajaran Jarak Jauh, Beliau juga mensyaratkan calon mempelai laki-laki untuk memiliki tempat tinggal yang tenang sehingga tujuan menikah dapat dicapai dengan mudah.
\end{abstract}

Kata Kunci : Nikah, Pandemi, Sakinah

\begin{abstract}
Marriage is a basic human need for adults. There are problems that often occur in marriage, especially if the marriage is an early marriage during a pandemic. Marriage between a man and a woman whose age is below the legal age limit and or marriage that does not have complete requirements. Islam maintains human honor, as well as regulates the generation of quality, noble character and clear lineage with marriage. This research is a descriptive qualitative research, while the data collection methods are based on literature, interviews and direct observations in the field. This process begins with marriage. Building a sakinah, mawaddah wa rahmah household will be achieved if knowledge about marriage is not too late and the prospective brides and grooms have prepared it. Marriage education according to $\mathrm{KH}$. Muhammad Kholil Bangkalan is given at elementary level education especially when education
\end{abstract}


Jurnal DinamikA

Volume 2 No. 2 (2021)

E-ISSN: $2723-1410$

Website: https://jurnal.iainsalatiga.ac.id/index.php/dinamika/index

utilizes the Internet network in Distance Learning, He also requires the prospective groom to have a quiet place to live so that the goal of marriage can be achieved easily.

Keywords: Marriage, Pandemic, Sakina

\section{A. Pendahuluan}

Pernikahan merupakan kebutuhan dasar manusia, sebagaimana kebutuhan untuk minum, makan dan juga berpakaian. Bahwa setiap manusia normal, pria maupun wanita memiliki hasrat biologis. Karena keinginan yang sama untuk merealisasikan kebutuhan biologisnya masing-masing, baik di masa normal ataupun di masa new normal seperti saat sekarang. ${ }^{1}$ Pernikahan menurut undang-undang perkawinan no 1 tahun 1974 adalah ikatan lahir-batin antara seseorang pria dan seorang wanita sebagai seorang suami-istri dengan tujuan membentuk keluarga yang bahagia dan kekal berdasar Ketuhanan yang Maha Esa. ${ }^{2}$

Namun demikian dalam pernikahan tak jarang menemui permasalahan, diantaranya kekerasan dalam rumah tangga, kesulitan ekonomi terlebih di masa Pemberlakuan Pembatasan Kegiatan Masyarakat (PPKM), ketidakcocokan pendapat hingga masalah kesehatan pasangan. ${ }^{3}$ Permasalahan-permasalahan tersebut rentan terjadi pada setiap pasangan, terlebih lagi apabila pasangan tersebut menikah dalam usia yang belum matang atau pernikahan dini.

${ }^{1}$ Abdul Basit, Bimbingan Perkawinan dalam Perspektif Al- Qur'an, Bimbingan Religi: Jurnal Bimbingan Bimbingan Islam, Vol. 7, No. 2, Desember 2016, hlm. 176

${ }^{2}$ UU No. 1 Tahun 1974 Tentang Perkawinan Pasal 1

${ }^{3}$ Satih Saidiyah, Very Julianto, Problem Pernikahan Dan Strategi Penyelesaiannya: Studi Kasus Pada Pasangan Suami Istri Dengan Usia Perkawinan Di Bawah Sepuluh Tahun, Jurnal Psikologi Undip Vol.15 No.2 Oktober 2016, hlm. 124-133 
Jurnal DinamikA

Volume 2 No. 2 (2021)

E-ISSN: 2723-1410

Website: https://jurnal.iainsalatiga.ac.id/index.php/dinamika/index

Pernikahan dini adalah pernikahan yang dilakukan sebelum batas diperbolehkannya menikah menurut peraturan perundang-undangan. Adapun batas usia menikah dalam Undang-Undang Perkawinan bab II Pasal 7 ayat 1, bahwa usia mempelai memenuhi syarat diperboleh diijinkan jika mempelai pria mencapai umur 19 tahun dan mempelai perempuan sudah mencapai umur 16 tahun. Keputusan pemerintah dalam menetapkan batasan usia minimal untuk menikah ini tentunya sudah melalui proses yang sangat panjang dan berbagai pertimbangan. Batasan usia ini memiliki tujuan agar calon kedua calon pengantin benar-benar telah siap dan matang dari aspek fisik, psikis, dan mehtal. ${ }^{4}$

Guna mengurai permasalahan seputar pernikahan dini dan dampaknya di atas, maka sangat perlu memberikan pendidikan nikah kepada para remaja khususnya, pendidikan dan pengajaran mengenai pengertian utamanya tentang syarat-syarat menikah baik bagi calon mempelai laki-laki dan juga perempuan. Sebab apabila pasangan menikah tanpa miliki syarat-syarat tersebut, maka rumah tangga mereka berpotensi gagal mencapai tujuan pernikahan sebagaimana dimaksudkan pada alinea pertama tadi. Dapat diibaratkan dengan seseorang yang mengendarai sepeda motor di jalan raya tanpa memiliki surat-surat kendaraan, tanpa SIM dan tidak mengenakan helm. Apabila ada pemeriksaan di jalan ataupun terjadi kecelakaan, maka dapat berakibat fatal.

Menurut Hurlock, sebab utama dari terlaksananya prosesi pernikahan sangat berpengaruh pada kehidupan rumah tangga pasangan tersebut selanjutnya. Orang

${ }^{4}$ Dwi Rifiani, Pernikahan Dini dalam Perspektif Hukum Islam, De Jure, Jurnal Syariah dan Hukum, Volume 3 Nomor 2, Desember 2011, hlm. 125-134 
Jurnal DinamikA

Volume 2 No. 2 (2021)

E-ISSN: 2723-1410

Website: https://jurnal.iainsalatiga.ac.id/index.php/dinamika/index

yang menikah terpaksa dikarenakan pasangan perempuannya telah mengandung janin (hamil sebelum ijab-qobul), kemungkinan untuk terjadinya perceraian jauh lebih besar daripada pernikahan biasa. ${ }^{5}$

Pernikahan dini pada pembahasan di sini dimaknai dengan kurangnya pengetahuan dan tidak lengkapnya persyaratan yang dimiliki oleh para calon pengantin, baik pengantin laki-laki dan pengantin perempuan. Dalam rangka mengetahui dan memahami tentang syarat-syarat untuk siap menikah inilah dapat disampaikan dengan metode tanya-jawab. Pertanyaan dan jawaban praktis dalam mengajarkan perihal pendidikan nikah untuk anak-anak dan para remaja. Bagaimanakah metode pengajaran nikah yang pernah dilakukan oleh ulama Nusantara KH. Muhammad Kholil Bangkalan?, apa sajakah syarat wajib menikah bagi calon pengantin laki-laki dan calon pengantin perempuan menurut $\mathrm{KH}$. Muhhamad kholil Bangkalan? Mengenai pertanyaan dan sekaligus jawabannya termuat dalam kitab beliau "As-Silah fi Bayani Nikah" atau "Tanya-jawab seputar Pernikahan.”

\section{A. Metode Penelitian.}

Penelitian ini adalah penelitian kualitatif deskriptif, adapun metode pengumpulan data berbasis kepustakaan, wawancara dan pengamatan langsung di lapangan. Studi kepustakaan dikerjakan dengan membaca, menelaah dan menuliskan berbagai literatur atau bahan bacaan yang sesuai dengan pokok bahasan,

5 Johan Reny Puspitasari dan Satiningsih, Perbedaan Penyesuaian Pernikahan pada Pasangan yang Menikah Muda, Jurnal Psikologi Teori dan Terapan 2014, Vol. 5, No. 1, 45-51, hlm. 46. 
Jurnal DinamikA

Volume 2 No. 2 (2021)

E-ISSN: 2723-1410

Website: https://jurnal.iainsalatiga.ac.id/index.php/dinamika/index

kemudian disaring dan dituangkan dalam kerangka pemikiran secara teoritis. Teknik ini dilakukan guna memperkuat fakta guna membandingkan perbedaan dan atau persamaan antara teori dan praktek yang sedang penulis teliti terkait masalah Pendidikan Nikah menurut KH. Muhammad Kholil Bangkalan dalan kitab As-Silah fi Bayani Nikah. ${ }^{6}$

\section{B. Pembahasan}

\section{Konsep Dasar Pernikahan dalam Islam}

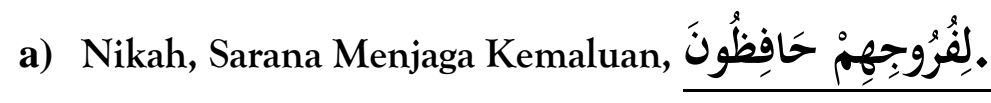

Nikah adalah sebuah kata yang telah diadopsi menjadi bahasa Indonesia, kata nikah aslinya adalah bahasa Arab adalah berasal dari nakaha-yankihunikaahan yang artinya kawin, setubuh. ${ }^{7}$ Adapun pengertian nikah adalah terbentuknya satu perjanjian yang kokoh antara seorang pra dan wanita sebagai pasangan suami-istri dengan harapan dapat membangun rumah tangga bahagia dan kekal berdasarkan Ketuhanan Yang Maha Esa. ${ }^{8}$

Alloh SWT Sang Maha Pencipta alam semesta menetapkan pernikahan sabagai satu-satunya sarana membangun rumah-tangga (cinta-kasih) religius. Pernikahan artinya membangun komunikasi intensif dua insan belainan jenis, pria dan wanita sebagai suami-istri terjalin dengan terhormat, kebutuhan dasar biologis

\footnotetext{
${ }^{6}$ Kartini Kartono, Pengantar Metodologi Research (Bandung : Alumni, 1998), hlm.78.

${ }^{7}$ Kamus Al-Munawir, (Surabaya : Pustaka Progressif, 2007), hlm. 1560.

${ }^{8}$ UU No. 1 Tahun 1974 tentang Perkawinan, pasal 1.
} 
Jurnal DinamikA

Volume 2 No. 2 (2021)

E-ISSN: 2723-1410

Website: https://jurnal.iainsalatiga.ac.id/index.php/dinamika/index

dapat tersalurkan, kepuasan dan kebahagiaan psikis emosional dapat tercapai sesuai fitrah dan kodrat manusia, di masa normal ataupun new normal.

Tujuan menikah yang mulia sebagaimana disebutkan dalam undang-undang perkawinan di atas dapat dikaitkan dengan semangat dasar kemanusiaan. Kita sebagai manusia normal perlu memenuhi kebutuhan hidup jasmani (kebutuhan biologis) dan ruhani, sekaligus guna membentuk keluarga yang merupakan sarana untuk meneruskan dan memelihara anak keturunan yang jelas.

Agama Islam sangat menjaga kemurnian generasi penerus kehidupan. Sehingga pasangan yang akan membangun rumah tangga perlu mempersiapkan ilmu dalam mengharungi bahtera rumah tangga untuk membangun sebuah keluarga bahagia dan sejahtera. ${ }^{9}$

Dalam surat an-Nisaa 4 : 16 Alloh SWT berfirman:

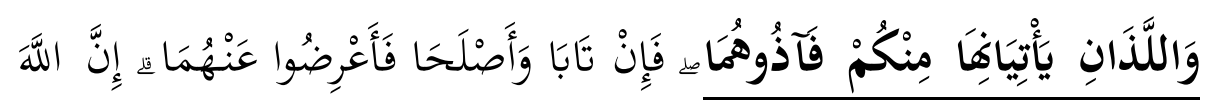

كَانَ تَوَّابًا رَحريمًا

Memaknai ayat di atas, Prof. Quraish Shihab menyatakan bahwasannya pelaku zina, keduanya dikenai hukuman yang sudah ditentukan. Sanksi pidana itu dapat diputuskan apabila perbuatan zina tersebut cukup alat bukti dan saksi, yaitu disaksikan oleh empat orang saksi yang adil. Selanjutnya, setelah dikenai hukuman tertentu, kemudian mereka bertobat, maka janganlah kalian sebut-sebut perbuatan

9 Khoiruddin Nasution. Perlindungan Terhadap Anak Dalam Hukum Keluarga Islam Indonesia, Al-'Adalah Vol. XIII, No. 1, tahun 2016, hlm. 3 
Jurnal DinamikA

Volume 2 No. 2 (2021)

E-ISSN: 2723-1410

Website: https://jurnal.iainsalatiga.ac.id/index.php/dinamika/index

mereka dan jangan pula kalian hina. Sesungguhnya Allah, dengan kasih sayang-Nya, akan menerima pertaubatan orang-orang yang bertaubat. ${ }^{10}$

Menurut Imam Syafi'i makna nikah secara istilah ialah akad ijab-qobul yang dengannya menghalalkan aktivitas yang sebelumnya dilarang, antara pria dan wanita, yaitu hubungan seks. ${ }^{11}$ Sedangkan menurut Al-Qur'an tujuan utama pernikahan adalah membentuk kehidupan keluarga kecil bahagia sejahtera yang terdiri atas suami, istri, anak-anak serta orang tua.

Dari pengertian pernikahan tersebut, maka jelaslah bahwa prinsip pokok adanya pernikahan dalam Islam adalah menjaga, menyalurkan hasrat sesuai kodrat manusia serta guna memelihara kemaluan manusia dari bahaya pergaulan bebas, penularan penyakit seksual dan menjaga kemurnian keturunan yang sah. Sehingga diantara ciri khas orang bertaqwa adalah mereka, laki-laki dan perempuan yang memelihara kemaluannya (QS. Al-Mu'minun: 5).

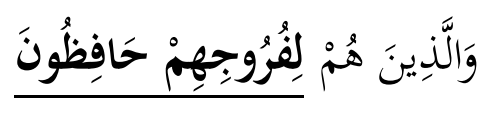

Artinya : Orang-orang yang beriman dari kaum laki-laki tersebut adalah bagian orangorang yang selalu memelihara kemaluan mereka agar tidak berhubungan dengan wanita yang bukan istrinya.

Ayat al-Qur'an surat al-Mu'minun ini bertalian erat dengan beberapa ayat di awal surat an-Nur yang membahas sanksi tegas atas pelaku pergaulan bebas. Pengertian dari firman Alloh SWT di atas menunjukkan kepada kita mengenai

${ }^{10}$ Quraish Shihab, Surat An-Nisa ayat 16, Tafsir Al-Misbah, dalam aplikasi Qur'an All in One versi 3.2.3 Tahun 2021

${ }^{11}$ KH. Muhammad Kholil Ibn Lathif al-Bangkalan, As-Silah fi Bayaani Nikah, Maktabah Tahmil, tahun 2021, hlm. 66 . 
Jurnal DinamikA

Volume 2 No. 2 (2021)

E-ISSN: 2723-1410

Website: https://jurnal.iainsalatiga.ac.id/index.php/dinamika/index

akibat buruk seks bebas. Segala pernak-pernik kehidupan seks dari zaman para Nabi dahulu hingga saat sekarang selalu muncul dan menjadi komoditas yang tidak ada habis-habisnya. Terlebih saat pandemi, para pelajar memiliki keleluasaan untuk menggunakan handphone yang terkoneksi dengan jaringan internet. Pornografi dengan segala bentuknya seolah tidak terbendung bahkan oleh internet baik yang dicetuskan oleh kementrian informasi di negeri tercinta ini.

Perzinaan karena pergaulan bebas tidak jarang membuahkan janin yang diaborsi ataupun kehamilan dan anak yang dilahirkan. Pergaulan bebas apabila menghasilkan keturunan (anak), maka anak yang dilahirkan tersebut akan sulit menentukan siapa bapaknya (nasabnya tidak jelas). Dampak buruk perzinaan dapat dibagi ke dalam dua kelompok. Kelompok pertama, dampak lahiriah dari zina adalah mengakibatkan penyakit menular seksual seperti gonore, spilis (raja singa), luka bernanah pada alat kelamin hingga AIDs yang belum ditemukan obatnya sampai sekarang.

Dalam keadaan gawat, gonore mengakibatkan komplikasi pada saluran kencing, persendian atau trakhoma yang dapat mengakibatkan kebutaan bagi penderitanya. Kelompok Kedua, dampaknya secara mental, perzinaan dapat menimbulkan perasaan bersalah dan berdosa, pada akhirnya dapat berakibat lemahnya saraf, sampai pada depresi dan kegilaan. ${ }^{12}$

Pernikahan adalah institusi terbaik dalam rangka memelihara kesucian kemaluan agar terhindar dari seks bebas di era pandemi. Karenanya pernikahan

${ }^{12}$ Quraish Shihab, Surat Al-Mukminun ayat : 5, Tafsir al-Misbah, dalam aplikasi Qur'an all in one versi 3.2.3 tahun 2021 
Jurnal DinamikA

Volume 2 No. 2 (2021)

E-ISSN: 2723-1410

Website: https://jurnal.iainsalatiga.ac.id/index.php/dinamika/index

merupakan suatu perbuatan yang mengandung nilai sakral dan ritual keagamaan ideal. Sangat bermanfaat guna memberikan fungsi dukungan pada pelaksanaan fungsi hidup manusia sebagai hamba dan khalifah Allah di atas muka bumi. Dengan demikian, pernikahan dalam Islam merupakan ibadah kepada Alloh SWT sekaligus mengikuti sunah Rasulullah.

Menurut pandangan Duvall dan Miller penulis buku "Marital Readiness," pernikahan adalah membangun pola interaksi antara laki-laki dan perempuan yang dimaklumi secara sosial kemasyarakatan, menyediakan hubungan cinta-kasih dan pendidikan anak yang sah dan didalamnya terjadi pembagian kerja yang jelas bagi masing-masing pihak baik suami maupun istri. ${ }^{13}$

Dalam hal ini pakar fiqh modern, Yusuf Qardhawi mengungkapkan, seandainya perkawinan tidak disunahkan Tuhan, hasrat seksual tidak dapat tersalurkan dan tidak ada institusi yang berperan dalam menjaga keberlangsungan keturunan manusia selanjutnya. Kalau sekiranya zina itu dibolehkan, hubungan seksual dalam kumpul kebo dibiarkan tanpa ikatan pernikahan, maka tidak akan terbentuk institusi keluarga yang berperan membangun unit sosial terkecil dan bernilai luhur, berupa rumah tangga idaman berasas cinta dan kasih sayang anak keturunan nabi Adam as.

Tingkat kematangan jasmani dan ruhani dalam pernikahan adalah menjadi dasar mencapai tujuan dan cita-cita dalam pernikahan, meski demikian masih banyak

13 Prayinda Elsa Nurmamita, Skripsi: Hubungan Antara Resolusi Konflik Dengan Kepuasan Pernikahan Pada Pasangan, (Surabaya: Universitas Islam Negeri Sunan Ampel Surabaya, Fakultas Psikologi, 2018), hlm. 2. 
Jurnal DinamikA

Volume 2 No. 2 (2021)

E-ISSN: $2723-1410$

Website: https://jurnal.iainsalatiga.ac.id/index.php/dinamika/index

anggota masyarakat kita yang kurang memperhatikan atau menyadarinya. Hal ini disebabkan adanya pengaruh pergaulan dan lingkungan sosial yang kurang memadai. ${ }^{14}$

b) Nikah, Membentuk Ikatan yang Kokoh, مِينَاقًا غَلَِيظًا.

Kapankah seseorang memerankan memiliki ikatan yang kuat antara suamiistri dalam keluarga?, tentu saja sejak ia melakukan akad nikah, itulah satu bentuk ikatan yang paling kokoh. Sejak saat itulah secara resmi dimulainya seseorang dirinya menjadi bagian terpenting dari sebuah keluarga. Pasangan laki-laki harus belajar menjadi suami yang baik, sedemikian pula pasangan perempuan hendaknya belajar menjadi istri yang baik dalam kehidupan keluarga baru mereka.

Hasbi Ash-Shiddieqy dalam bukunya Hukum-Hukum Fiqh Islam ketika memberikan pengertian tentang pernikahan yaitu "Nikah, suatu aqad syar'i (ikatan keagamaan) yang dianjurkan syara.”

Ditegaskan dalam surat An-Nisaa $4: 21$

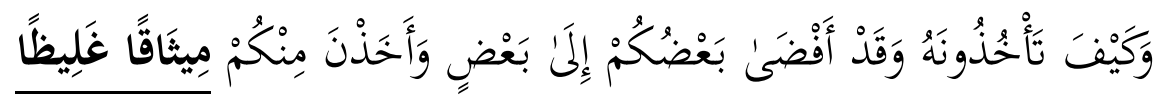

Artinya: Bagaimana kamu sekalian enak hati apabila meminta kembali mahar perkawinan yang telah kamu berikan, padahal kalian telah saling bergaul sebagai pasangan suami-istri dan istri-istri kalian telah berjanji yang kokoh dan secara sah untuk menjadi pasangan yang baik. ${ }^{15}$

14 Rosramadhana dan Nofriani Taufan, Fenomena Perkawinan Dini di Kalangan Perempuan Jawa Deli -Deli Serdang, Anthropos: Jurnal Antropologi Sosial dan Budaya 2 (1) (2016), hlm. 62-75.

${ }^{15}$ Al-Qur'an Surat An-Nisa : 21 
Jurnal DinamikA

Volume 2 No. 2 (2021)

E-ISSN: $2723-1410$

Website: https://jurnal.iainsalatiga.ac.id/index.php/dinamika/index

Pasal 2 Kompilasi Hukum Islam (KHI) memberikan batasan tentang pernikahan atau perkawinan, yaitu akad yang sangat kuat atau mitsaqan ghalidzan untuk mentaati perintah Alloh SWT dan melaksanakannya merupakan ibadah dalam sebuah ikatan yang sah.

Dengan mensyariatkan nikah, tentunya Alloh juga mempunyai aturan yang tidak boleh dilanggar, khususnya bagi calon suami saat hendak memilih perempuan sebagai pasangan, hal ini terdapat dalam surat An-Nisaa $4: 23$

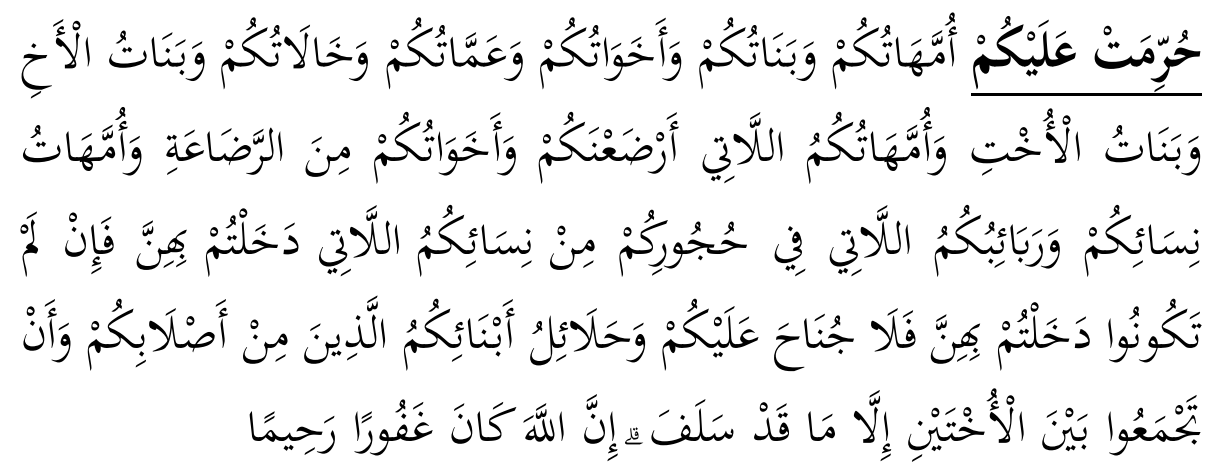

Artinya : Dilarang bagi kamu sakalian untuk menikahi ibumu, anak perempuanmu, saudara perempuanmu, saudara perempuan ayahmu, saudara perempuan ibumu, anak perempuan dari saudara perempuanmu, ibu susu, saudara perempuan yang menyusuimu, dan ibu mertuamu. Selain itu, haram juga bagimu untuk menikahi anak tiri dari istri yang telah kamu kencani, dan istri dari anak kandungmu (menantu) dan menikahi dua wanita yang bersaudara, kecuali apa yang telah terjadi sejak zaman jahiliyah. Untuk yang satu ini, Alloh SWT telah memaafkannya. Sesungguhnya Alloh SWT Maha Pengampun dari semua yang terjadi sebelum aturan ini datang dan sangat mencintaimu setiap kali Dia menetapkan ketentuan hukum. ${ }^{16}$

Syariat Islam merupakan satu-satunya syariat yang melarang perkawinan karena hubungan saudara satu penyusuan. Secara logika bayi kecil yang disusui oleh seorang ibu susu kedudukannya dengan bayi yang dilahirkan langsung oleh ibu susu

${ }^{16}$ Al-Qur'an Surat An-Nisa : 23 
Jurnal DinamikA

Volume 2 No. 2 (2021)

E-ISSN: 2723-1410

Website: https://jurnal.iainsalatiga.ac.id/index.php/dinamika/index

tersebut, sama dalam hal mengambil makanan darinya melalui air susu yang diminum. Sehingga ibu susu haram dinikahi karena statusnya sama dengan anak dari si ibu susu.

Sebelum ilmu yang mempelajari secara detail mengnai garis keturunan ditemukan, ayat ini telah mengungkapkan larangan pernikahan antar kerabat dekat. Ilmu kedokteran kemudian menemukan alasan ilmiah bahwa perkawinan semacam itu menyebabkan keturunan rentan terhadap penyakit, cacat fisik, dan tingkat kesuburan rendah yang bahkan mendekati kemungkinan kemandulan. Namun, sebaliknya, perkawinan dengan seseorang yang tidak memiliki hubungan kekerabatan tidak akan membuahkan hasil yang seperti dikhawatirkan. Keturunan dari pasangan yang bukan dari kerabat dekat akan memiliki keunggulan dalam hal kepribadian, keunggulan fisik, daya tahan yang kuat, pertumbuhan yang cepat dan kematian yang rendah.

Selanjutnya, sebelum memasuki kehidupan rumah-tangga yang lebih sempurna dengan lahirnya anak keturunan, Al-Qur'an memberikan petunjuk dan sekaligus pendidikan pentingnya menjaga nasab/keturunan. ${ }^{17}$

\section{c) Pernikahan, Sarana Mendidik Nasab/Keturunan, نَسَبَّا}

Sebagaimana bapak para Nabi Ibrahim as dan juga Ya'kub yang mempersiapkan generasinya dengan kalimat tauhid, sedemikian halnya, Siti Maryam

\footnotetext{
${ }^{17}$ Al-Qur'an, surat Al-Baqarah: 132-133
} 
Jurnal DinamikA

Volume 2 No. 2 (2021)

E-ISSN: $2723-1410$

Website: https://jurnal.iainsalatiga.ac.id/index.php/dinamika/index

dan Luqmanul Hakim membina ketauhidan dan akhlak mulai kepada anak-anak keturunan mereka.

Dalam surat Al-Furqaan, surat al-Baqoroh dan surat Luqman berikut ini:

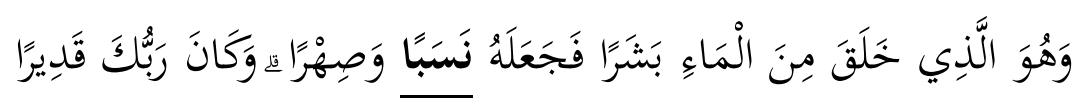

Artinya : Alloh SWT telah menciptakan umat manusia dari setetes air yang hina (sperma). Kemudian Alloh SWT menjadikan mereka pria dan wanita memiliki hubungan yang lebih kuat melalui anak keturunan atau perkawinan. Alloh Maha Kuasa atas segala sesuatu yang Dia kehendaki. ${ }^{18}$

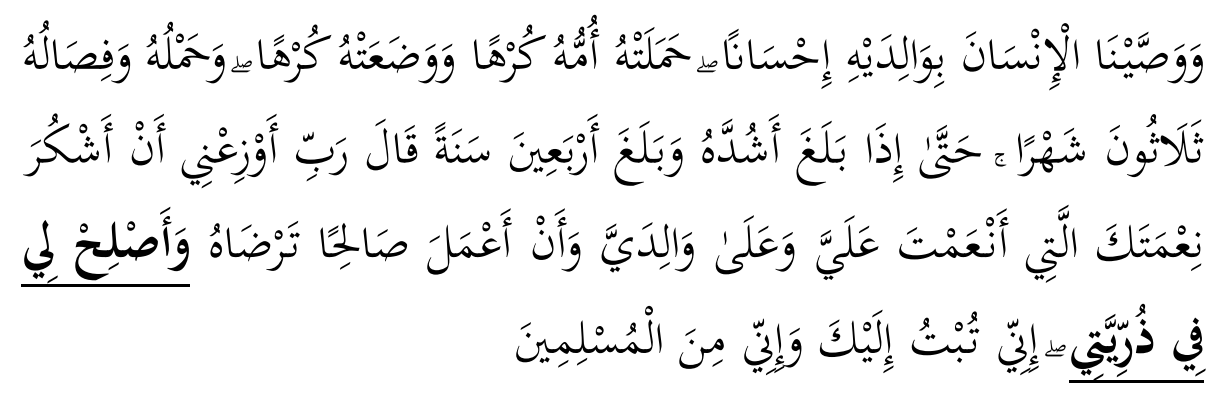

Artinya : "Alloh SWT mewasiatkan kepada seluruh manusia untuk berbuat baik kepada Ibu dan Bapaknya. Ibunya telah mengandung dan melahirkannya dengan segenap perjuangan. Selama masa kehamilan dan penyapihan selama 30 bulan, sang ibu merasakan berbagai pengorbanan. Ketika anak itu telah dewasa dan mencapai usia empat puluh tahun, ia berdoa, "Ya Tuhanku, berilah aku petunjuk untuk mensyukuri nikmat-Mu yang telah Engkau berikan kepadaku dan kepada kedua orang tuaku. ridhoi. Jadikan anak cucuku sebagai orang-orang yang bertakwa. Sesungguhnya aku bertobat kepada-Mu dari segala dosa, dan aku termasuk orangorang yang berserah diri kepada-Mu." ${ }^{19}$

Berbekal tiga ayat tersebut di atas, kita memiliki informasi lengkap tentang proses berketurunan dimulai dari pernikahan, persenggamaan, bertemunya sel sperma dengan sel telur, selanjutnya berbentuk segumpal darah, janin hingga sempurna menjadi bayi manusia memerlukan waktu setidaknya berlangsung selama

\footnotetext{
${ }^{18}$ Al-Qur'an, surat Al-Furqaan: 54

${ }^{19}$ Al-Qur'an Al-Ahqaf $46: 15$
} 
Jurnal DinamikA

Volume 2 No. 2 (2021)

E-ISSN: 2723-1410

Website: https://jurnal.iainsalatiga.ac.id/index.php/dinamika/index

enam bulan. Keadaan orang-tua khususnya ibu pada masa tersebut adalah sangat lelah dan bertambah lemah. Sampai tiba saatnya dilahirkan kemudian menyusui sampai menyapih dalam kurun waktu 24 bulan (dua tahun) sampai dengan 30 bulan (dua tahun setengah).

Semenjak masa dalam kandungan, dilahirkan, disusui, anak balita, remaja, semuanya itu merupakan masa pengasuhan/pendidikan guna mempersiapkan generasi yang beriman dan bertaqwa kepada Tuhan Yang Maha Esa, Alloh SWT.

Ibu adalah madrasah pertama bagi putra-putrinya, jika baik pengasuhan seorang ibu atas anak-anaknya, maka akan tumbuh menjadi anak-anak yang hebat guna bertahan hidup dan berkompetisi di era new normal yang mungkin saja masih akan berlangsung di dekade ini. Hasil pendidikan pertama dan utama dari sisi keluarga inti yang telah diterangkan dalam firman Tuhan tersebut dapat menjadi ibarat bagi kita dalam memulai proses pembentukan keluarga dan anak keturunan yang bersandarkan kepada nilai-nilai agama Islam. Lebih jauh lagi, kitab suci umat Islam mengajarkan kepada bukan hanya umat Islam, namun kepada semua seluruh manusia agar mempersiapkan keturunan. Supaya tidak meninggalkan anak keturunan yang lemah iman, taqwa dan juga perekonomiannya.

Surat An-Nisaa $4: 9$

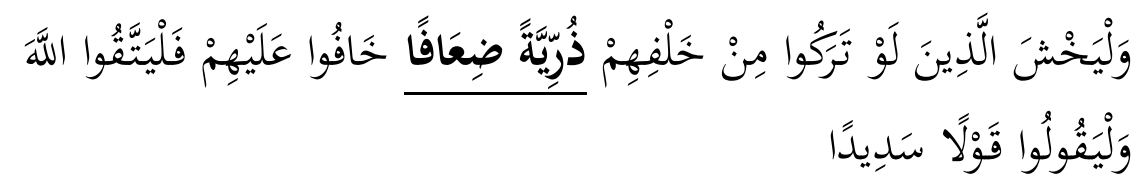

Artinya : "Manusia sekali-kali tidak boleh berlaku zalim terhadap anak-anak yatim. Hendaklah kita orang Islam merasa takut terhadap generasi anak keturunan kita yang lemah akan menerima perlakuan zalim sebagaimana yang dirasakan oleh anak-anak yatim. Bertakwalah kepada Allah dalam menghadapi anak-anak yatim. Berbicaralah 
Jurnal DinamikA

Volume 2 No. 2 (2021)

E-ISSN: 2723-1410

Website: https://jurnal.iainsalatiga.ac.id/index.php/dinamika/index

dengan ucapan yang mengarah kepada kebenaran tanpa berlaku zalim kepada siapa pun.”

Menikah sama artinya dengan mempersiapkan generasi yang tangguh, terampil, sebagai anak keturunan yang memiliki tingkat kesiapan tinggi dalam menghadapi kemajuan zamannya nanti. Dalam hal ini penting sekali peran aktif sebuah keluarga, keluarga kecil yang di dalamnya terdapat sosok suami atau ayah sebagai kepala keluarga, ia memiliki kewajiban bekerja menafkahi istri dan anakanaknya. Di dalamnya juga terdapat sosok Ibu yang mengelola rumah-tangga sekaligus mendidik putra-putrinya saat sang suami bekerja di luar rumah.

Dari zaman dahulu hingga zaman sekarang ini, faktor kesulitan ekonomi keluarga seringkali menjadi penyebab terjadinya keretakan hingga mengakibatkan konflik suami-istri hingga berujung pada perceraian. Seperti yang dilaporkan Pada 2020, persentase perceraian secara nasional naik menjadi 6,4 persen dari 72,9 juta rumah tangga atau sekitar 4,7 juta pasangan, bahkan di Kabupaten Kendal Jawa Tengah persentase perceraian naik cukup tinggi, yakni dari 4,6 persen menjadi 9,1 persen. Data yang sama menunjukkan, tingkat perceraian di Kendal pada 2015 masih di bawah rata-rata nasional (5,9 persen), tapi pada 2020 sudah di atas $\left(6,4\right.$ persen) ${ }^{20}$ Kemudian guna mengharmoniskan hubungan suami-istri dalam rumah tangga, Al-Qur'an memerintahkan suami agar mempergauli istrinya dengan cara yang baik atau "bil ma'ruf". ${ }^{21}$

20 Anindhita Maharrani, Perceraian di Indonesia Terus Meningkat, (https://lokadata.id/artikel diakses pada tanggal 5 Agustus 2021)

${ }^{21}$ Al-Qur'an, surat An-Nisa: 19 
Jurnal DinamikA

Volume 2 No. 2 (2021)

E-ISSN: 2723-1410

Website: https://jurnal.iainsalatiga.ac.id/index.php/dinamika/index

Pengertian dengan cara yang baik dalam ayat ini dapat dimaknai dengan saling memahami. Pemakaian kata "ma'ruf" guna menjelaskan bahwasannya ikatan suami istri tidak hanya didasari dengan ikatan cinta semata-mata, tetapi lebih penting dari hal tersebut, hendaknya ikatan suami-istri berlandaskan pada nilai-nilai Islami yang dengannya dapat terus menjaga keutuhan dan keharmonisan kehidupan berumah-tangga tersebut. Sehingga biduk rumah tangga tidak mudah pecah terkena gelombang ombak dan badai kehidupan yang diarungi terlebih di era pandemi yang cukup berat ini.

Sahabat Umar bin Khottob ra. mengecam kepada pasangan yang menceraikan isterinya dikarenakan hanya persoalan belum tumbuhnya rasa saling mencintai. Umar bin Khottob ra. mengatakan, "apakah rumah tangga hanya dibina atas dasar cinta? Kalau demikian mana nilai-nilai luhur? Mana pemeliharaan, mana amanah yang engkau terima?.”

Lebih rinci lagi, kalam Alloh SWT mengajarkan kita umat Islam dan manusia pada umumnya untuk hidup bersama antara suami-istri dalam rumah tangga yang bahagia, disebabkan antara keduanya diwajibkan untuk saling mengerti dan saling memahami. Hubungan istri-suami diibaratkan dengan mengenakan pakaian yang menjadi kebutuhan pokok manusia, "mereka (para istri) menjadi pakaian bagi kamu dan kamu pun adalah pakaian bagi mereka."22

Surat Al-Baqara $2: 187$

${ }^{22}$ Al-Qur'an Surat Al-Baqarah: 187 


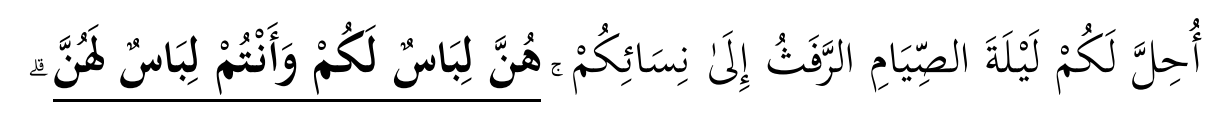

Artinya : Alloh SWT telah menghalalkan bagi kalian semua untuk bersetubuh dengan istri kalian pada malam hari di bulan puasa sebagai bentuk kelegaan, karena istri-istrimu ibarat pakaian bagimu dan kamu adalah pakaian bagi istri-istrimu.

Jika saja pakaian yang kita kenakan memiliki manfaat guna menutupi badan dan melindungi kita dari kedinginan, maka suami-istri hendaknya saling melengkapi, saling menutupi kekurangan antara satu dengan lainnya. Di samping itu pakaian memiliki fungsi keindahan bagi pemakaiannya, maka istri adalah keindahan bagi suaminya dan sebaliknya.

Secara khusus pendidikan guna mempersiapkan generasi yang lebih baik ini diperoleh pasangan pengantin hanya beberapa saat sebelum resmi menikah, yakni pada pendidikan pra pernikahan untuk calon pengantin (catin), namun ada pula yang telah menjadikan materi ini sebagai bagian dari kurikulum khususnya pada madrasah tsanawiyah dan madrasah aliyah.

Menurut Okun, pakar pendidikan keluarga dari Inggris berpendapat bahwasannya pendidikan pernikahan dan bimbingan membangun rumah tangga hendaknya menggunakan metode yang berbeda antar tiap pasangan. Pendidikan nikah bagi calon pengantin hendaknya menggunakan pendekatan psychodynamic, clientcentered dan behavioral (the marriage counseling literature emphasizes the psychodynamic, client-centered and behavioral views). Artinya teori mengenai pendidikan untuk membangun keluarga ini tidak bisa dipukul rata atau digeneralisasikan untuk 
Jurnal DinamikA

Volume 2 No. 2 (2021)

E-ISSN: 2723-1410

Website: https://jurnal.iainsalatiga.ac.id/index.php/dinamika/index

semua pasangan, hendaknya berbasis pada keunikan setiap individu dan kebiasaan mereka. $^{23}$

\section{d) Nikah, Ajaran untuk Memuliakan Kaum Perempuan, زَوَجَةً .}

Dengan menikah maka seorang perempuan menjadi lebih mulia kedudukannya, sebab ia menyandang status sebagai istri yang sah dan calon ibu bagi anak-anaknya. Surat Al-Ahzaab 33 : 59

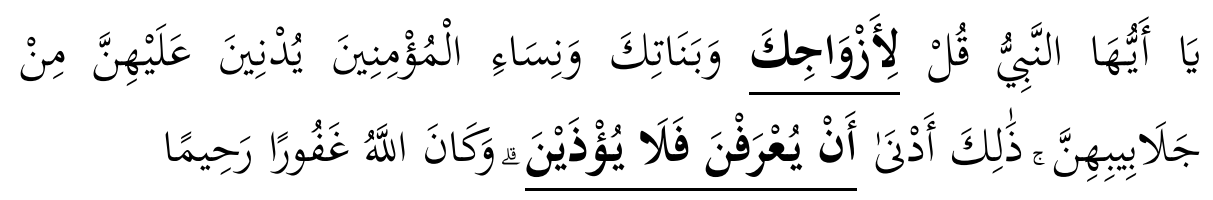

Artinya : Wahai Nabi Muhammad, perintahkanlah kepada istri-istrimu dan semua wanita beriman untuk memanjangkan jilbab sehingga menutupi seluruh tubuh. Pakaian dalam bentuk seperti itu akan lebih tepat dan benar sehingga mudah dikenali dan tidak mudah terganggu. Allah Maha Pengampun dan Maha Penyayang bagi orang-orang yang meninggalkan anak-anaknya.

Namun apabila pernikahan terpaksa gagal karena berbagai sebab yang tidak dapat didamaikan, istri tetap dimuliakan dengan sejumlah hak yang dimilikinya, yaitu hak memperoleh tempat tinggal dan nafkah yang layak selama masa iddah.

Apabila terjadi perselisihan pendapat antara suami-istri hingga menyebabkan konflik dalam rumah tangga, maka sangat perlu untuk didamaikan, baik secara langsung maupun dengan perantara pihak ketiga.

Al-Qur'an surat An-Nisaa $4: 35$

${ }^{23}$ Okun, Barbara F, Marriage and Family Counseling. (Boston: Northeastern University. 1984) hlm. 17. 


\section{وَإِنْ خِفْتُمْ شِقَاقَ بَيْنِهِمَا فَابْعَثُوا حَكَمًا مِنْ أَهْلِهِهِ وَحَكَمًا مِنْ أَهْلِهَها إِنْ يُرِيدَا

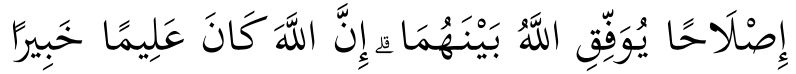

Artinya : "Jika terjadi perselisihan di antara sepasang suami-istri, dan kalian khawatir perselisihan itu akan berakhir dengan perceraian, tentukanlah dua orang penengah: yang pertama dari pihak keluarga suami, dan yang kedua dari pihak keluarga istri. Kalau pasangan suami-istri itu benar-benar menginginkan kebaikan, Allah pasti akan memberikan jalan kepada keadaan yang lebih baik, baik berupa keharmonisan rumah tangga maupun perceraian secara baik-baik. Sesungguhnya Allah Maha Mengetahui perbuatan lahir dan batin hamba-hamba-Nya."

Namun apabila langkah-langkah perdamaian antara suami-istri tidak dapat menyelesaikan persoalan, maka tidak ada pilihan lain kecuali dijatuhkan kata putus/talaq oleh suami kepada istrinya, atau gugatan cerai dari istri kepada suaminya.

Talaq adalah pemutusan ikatan pernikahan. Talaq makruh hukumnya, boleh namun dibenci oleh Alloh SWT. Baik yang dilakukan oleh suami ataupun gugatan cerai oleh istri. Ini bisa terjadi apabila kondisi benar-benar tidak bisa diperbaiki dan mediasi gagal memperoleh kata sepakat.

Sangat perlu mengupayakan jalan perdamaian apabila terjadi perselisihan antara suami-istri dalam pernikahan. Diharapkan dengan adanya perantara dapat tercapai perdamaian dan hubungan dapat dilanjutkan dengan lebih bijaksana dan menuju kemaslahatan keluarga.

Surat At-Talaaq $65: 1$

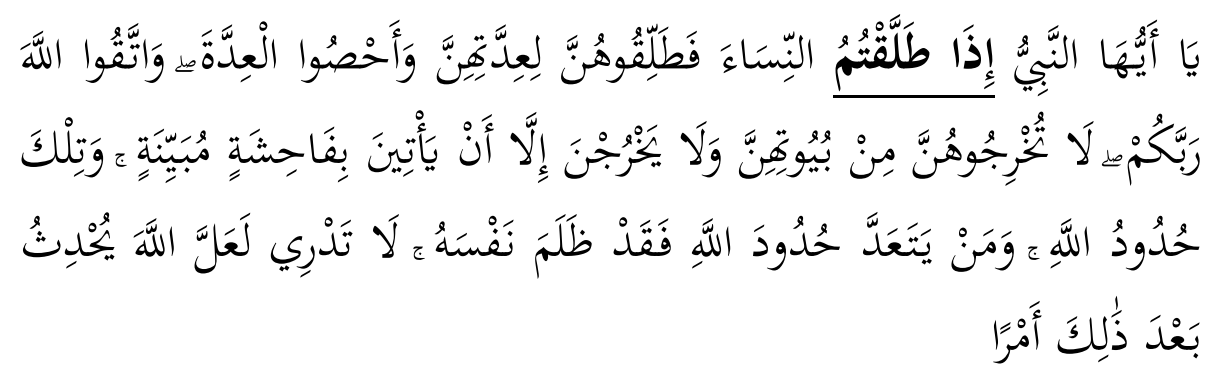


Jurnal DinamikA

Volume 2 No. 2 (2021)

E-ISSN: 2723-1410

Website: https://jurnal.iainsalatiga.ac.id/index.php/dinamika/index

Artinya : Wahai Nabi Muhamad, jika kamu menjatuhkan talaq kepada istri-istrimu maka jatuhkanlah talaq itu ketika mereka sedang dalam keadaan tidak sedang haid. Tepatkanlah hitungan masa idah dan bertakwalah kepada Tuhanmu. Jangan izinkan istri-istri yang kamu jatuhi talak itu keluar dari tempat rumahmu. Jangan memberikan izin kepada istri yang telah engkau talaq keluar rumah kecuali jika ingin melakukan perbuatan keji yang nyata. Ketentuan-ketentuan itu merupakan hukum yang telah ditetapkan oleh Allah untuk para hamba-Nya. Barangsiapa yang melanggar ketentuan Allah maka sesungguhnya ia telah mendzalimi diri sendiri. Kamu, hai orang yang melanggar, tidak mengetahui barangkali Allah akan mewujudkan sesuatu yang tidak diperkirakan, sesudah talaq itu, sehingga kedua pasangan suami-istri yang saling menyayangi kembali setelah perceraian itu. ${ }^{24}$

Surat ini membahas bolehnya menjatuhkan talak dan masa idah. Diantaranya adalah bahwa istri yang sedang dalam masa idah harus tetap tinggal di rumah tempat ia dijatuhi talak, kewajiban suami memberi nafkah dan tempat tinggal kepadanya dan sebagainya.

Sekali lagi perlu kita memahami bahwasannya talaq itu dilakukan sebagai pilihan paling akhir untuk menyelesaikan permasalahan dalam rumah tangga. Karena talaq ini menjadi solusi masalah rumah-tangga Islami, sehingga perlu dibarengi dengan rasa ikhlas dan tanggung jawab serta keyakinan penuh bahwa penyelesaian dengan menjatuhkan talak tersebut sebagai jalan terakhir terbaik.

Apabila terjadi talaq, maka berlakulah ketentuan sebagai berikut: Pertama, suami-istri boleh kembali tanpa akad nikah yang baru apabila talaq yang dijatuhkan belum sampai pada hitungan tiga kali dan istri masih berada dalam masa idah. Kedua, pasangan suami-istri tersebut harus melakukan akad nikah baru, apabila talaq yang dijatuhkan tersebut belum pada talaq hitungan ketiga kali sedangkan istri tertalaq telah selesai dari masa idahnya. Ketiga, pasangan suami-istri tidak diperkenankan

${ }^{24}$ Al-Qur'an, Surat Ath-Thalaq ayat : 1 
Jurnal DinamikA

Volume 2 No. 2 (2021)

E-ISSN: 2723-1410

Website: https://jurnal.iainsalatiga.ac.id/index.php/dinamika/index

kembali dalam pernikahan sebelumnya apabila telah dijatuhkan talaq tiga atau talaq telah terjadi tiga kali, kecuali istri tertalaq telah menikah dengan pria selainnya dan kemudian diceraikan pula oleh suami pada pernikahan keduanya tadi.

Kewajiban nafkah suami kepada istri yang telah ditalaq selesai saat masa idah berakhir, namun kewajiban nafkah suami kepada anak-anak tetap dibebankan kepada suami sampai anak mencapai usia baligh, atau sekitar 15 tahun, demi menjaga kelangsungan hidup dan masa depan anak, hasil pernikahan tersebut.

\section{Pendidikan Nikah Menurut KH. Muhammad Kholil Bangkalan}

a) Memasukkan Pendidikan Nikah pada Kurikulum Pendidikan Dasar dan Menengah pada Pembelajaran Jarak Jauh di Era Pandemi.

Pendidikan seks dalam pernikahan masih sangat minim, terutama pada pendidikan dasar dan menengah. Hal ini menyebabkan anak-anak mencari sendiri melalui internet, pengetahuan dari internet yang tidak terbimbing di saat pembelajaran jarak jauh ini bisa mendorong terjadinya hubungan seks remaja di luar nikah sehingga mengakibatkan kehamilan sebelum menikah yang mendorong banyaknya angka pernikahan dini.

Anak-anak sangat rentan terhadap kejahatan seksual. Dan yang lebih mempritahinkan lagi adalah pelaku kejahatan seksual terhadap anak itu bukanlah orang yang asing bagi anak-anak; mereka adalah orang-orang dekat di dalam kehidupan anak-anak yang menjadi korban kejahatan seksual tersebut.

Kemajuan teknologi informatika di dunia modern saat sekarang memiliki dua sisi yang berbeda, khususnya bagi anak-anak. Sisi pertama dapat bermanfaat 
Jurnal DinamikA

Volume 2 No. 2 (2021)

E-ISSN: 2723-1410

Website: https://jurnal.iainsalatiga.ac.id/index.php/dinamika/index

sebagai sarana belajar guna meningkatkan ilmu pengetahuan, memudahkan komunikasi jarak jauh dan juga sebagai media media hiburan. Namun di satu sisi lainnya bisa membahayakan apabila tidak didampingi dan dikontrol oleh para orang tua. Perkembangan video porno dan game online dapat merubah perilaku anak-anak dan menyebabkan kecanduan.

Data dari badan kesehatan dunia menyebutkan bahwa di Indonesia, remaja perempuan usia 15-19 tahun yang belum menikah tetapi sudah melakukan hubungan seks dengan lawan jenis sebanyak 34,7\%, sedangkan pada remaja laki-laki sebanyak 30,9\%. Adapun remaja yang setuju dan mengaku pernah berhubungan seks di luar nikah hampir $12,4 \%$, remaja yang hamil di luar nikah sebanyak 2,3\% dan pada usia di atasnya, 20 - 24 tahun sebanyak $68,2 \% .^{25}$

Oleh karena itu, pendidikan nikah adalah suatu kebutuhan yang mendesak dan mulai sekarang sebaiknya tidak dianggap tabu. Pengetahuan yang terstruktur dan sistematis bagi para remaja seputar hubungan suami-istri dalam pernikahan diharapkan dapat meminimalisir hubungan seks di luar nikah dengan segala akibat buruknya.

Inilah sebabnya karya KH. Muhammad Kholil Bangkalan menulis kitab "AsSilah fi Bayani Nikah" dijilid dalam satu rangkaian dengan kitab "Nadzom Safinatunnajah, Tanwirul Hija" karya Syekh Ahmad Bin Shodiq Bin 'Abdullah Pasuruan. Kitab Nadzom Safinatunajah, Tanwirul Hija ini kitab tipis

${ }^{25}$ Nana Astriana, Pendidikan Seks Dalam Proses Pembelajaran (Studi Deksriptif Pada Guru Di SMA Negeri 2 Makassar), Jurnal Sosialisasi Pendidikan Sosiologi-FIS UNM, Tahun 2017, hlm. 101 . 
Jurnal DinamikA

Volume 2 No. 2 (2021)

E-ISSN: 2723-1410

Website: https://jurnal.iainsalatiga.ac.id/index.php/dinamika/index

berisi ilmu fiqih dasar, membahas tentang rukun wudhu, rukun sholat, puasa dan sebagainya.

Dari sini dapat diambil pengertian bahwa setelah memahami ilmu fiqih dasar, maka tahap berikutnya, kita dianjurkan sesepuh ulama Nusantara KH. Muhammad Kholil Bangkalan untuk mempelajari ilmu penting berikutnya, yaitu tanya jawab seputar pernikahan dalam "As-Silah fi Bayani Nikah.” Dan pembelajaran tentang nikah ini diseyogyakan semenjak usia anak-anak atau usia sebelum 16 sebagaimana undang-undang perkawinan menetapkan batasan usia menikah untuk perempuan adalah 16 tahun. Hal ini pun telah ditunjukkan dalam al-Qur'an surat An-Nisaa $4: 3$

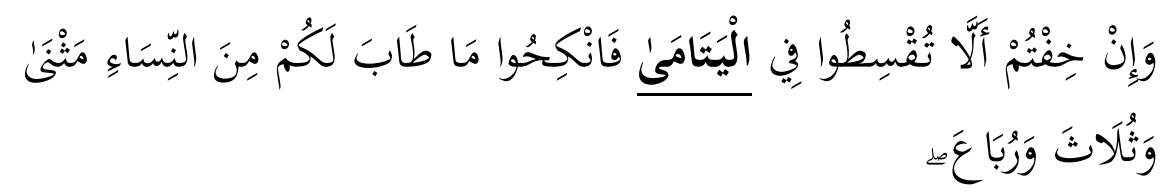

Artinya: Jika kamu khawatir berbuat aniaya kepada anak-anak yatim, karena itu adalah dosa besar, maka takut juga akan penderitaan yang akan dialami oleh istriistrimu jika kamu tidak memperlakukan mereka dengan adil dan jika kamu menikahi lebih dari empat istri.

Surat An-Nisaa $4: 6$

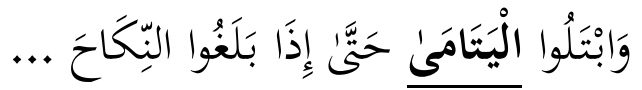

Artinya : Uji keterampilan berfikir anak-anak yatim, selidiki keadaan mereka dan kemampuan mereka menggunakan harta sebelum mereka dewasa. Jika mereka telah memenuhi syarat untuk menikah ...

Terlebih lagi apabila kita memahami bahwasannya ajaran nikah merupakan salah satu garis dari empat pilar pokok ajaran fikih, dikarenakan pada batang tubuh ajaran fikih terdapat empat garis penataan a). rub'al Ibadat, menata hubungan 
Jurnal DinamikA

Volume 2 No. 2 (2021)

E-ISSN: 2723-1410

Website: https://jurnal.iainsalatiga.ac.id/index.php/dinamika/index

manusia selaku makhluk dengan Alloh SWT. b). rub`al-muamalat, menata hubungan manusia dalam lalu lintas pergaulannya dengan sesamanya untuk memenuhi hajat hidupnya sehari-hari. c). rub`al-munakahat, yaitu yang menata hubungan manusia dalam lingkungan keluarga dan d). rub`al-jinayat, yang menata pengamanannya dalam suatu tertib pergaulan yang menjamin ketenteramannya. ${ }^{26}$

\section{b) Menikah Hendaknya dilakukan Apabila Telah Memenuhi 5} Syarat-syaratnya.

Pernikahan dinyatakan sah apabila memenuhi rukun dan syarat-syaratnya. Adapun yang termasuk dalam rukun perkawinan adalah sebagai berikut: Pihak-pihak yang melaksanakan akad nikah yaitu mempelai pria dan wanita. Adanya akad (sighat) yaitu perkataan dari pihak wali perempuan atau wakilnya (ijab) dan diterima oleh pihak laki-laki atau wakilnya (kabul). Adanya wali dari calon istri. Adanya dua orang saksi. $^{27}$

Apabila salah satu rukun tersebut itu tidak dipenuhi maka pernikahan tersebut dianggap tidak sah, dan dianggap tidak pernah ada pernikahan. Oleh karena itu diharamkan bagi pasangan yang tidak memenuhi rukun tersebut untuk mengadakan hubungan seksual maupun segala larangan agama dalam pergaulan.

Secara umum menikah yang harus dimiliki oleh calon mempelai laki-laki adalah adalah sebagai berikut: ${ }^{28}$

${ }^{26}$ Lathifah Munawaroh, Tes Kesehatan Sebagai Syarat Pra Nikah (Studi UU Pernikahan di Kuwait), Yudisia : Jurnal Pemikiran Hukum Dan Hukum Islam, Volume 10, Nomor 1, Juni 2019, hlm. 100.

${ }^{27}$ Andi Syahraeni, Nikah Dalam Perspektif Al Qur'an, Jurnal Al hikmah Vol. XIX No.2/2017, hlm. 14-15.

${ }^{28}$ Abd al-Rahman al-Jaziri, al-Fiqh 'ala al-Madhahib al-Arba'ah, (Bairut: Dar al-Kutub al-Ilmiah, 2003), hlm. 16. 
Jurnal DinamikA

Volume 2 No. 2 (2021)

E-ISSN: $2723-1410$

Website: https://jurnal.iainsalatiga.ac.id/index.php/dinamika/index

1. Calon suami:
a) Beragama Islam.
b) Laki-laki.
c) Jelas orangnya (bukan khunsa (banci) musykil).
d) Dapat memberikan persetujuan.
e) Tidak terdapat halangan pernikahan.

2. Calon Istri
a) Beragama Islam,
b) Tidak terdapat halangan pernikahan.
c) Jelas orangnya dan jelas bahwa ia adalah seorang wanita.
d) Dapat dimintai persetujuannya.
e) Tidak sedang melakukan ihram.

Di samping syarat wajib bagi calon suami dan calon istri sebagaimana tertulis di atas, terdapat syarat wajib tambahan yang diberlakukan di beberapa negara seperti Kuwait dan Jordan, yaitu syarat yang mewajibkan tes kesehatan sebagai pasangan yang hendak menikah.

Pemeriksaan kesehatan dengan vaksin covid-19, test swab antigen, dan suntikan tetanus merupakan salah satu penerapan yang berstatus ijtihadiyah, dimana secara praktek dan penerapannya disesuaikan dan ditentukan berdasarkan kebutuhan dan kemaslahatan. Penerapannya dapat bersifat mengikat bila pemerintah dalam hal ini ikut berperan serta, baik dalam tataran pembentukan 
Jurnal DinamikA

Volume 2 No. 2 (2021)

E-ISSN: 2723-1410

Website: https://jurnal.iainsalatiga.ac.id/index.php/dinamika/index

perundang-undangan ataupun wewenang dan kewajiban memberikan fasailitas bagi warganya menuju rumah tangga yang sehat. ${ }^{29}$

Di negara Indonesia, di saat pandemi covid-19 ini pasangan yang hendak menikah dipersyaratkan dengan telah memiliki sertifikat vaksin dan test swab antigen, disamping Imunisasi Tetanus Toksoid (TT) bagi calon pengantin wanita. Tujuannya agar setiap pasangan menikah dalam keadaan sehat dan tidak berpotensi menularkan penyakit, khusus imunisasi TT bagi calon pengantin wanita adalah agar dirinya ataupun bayi yang akan dilahirkan kelak terbebas dari infeksi tetanus.

Berikut ini lima syarat wajib menikah bagi calon suami dan lima syarat wajib menikah bagi calon istri menurut KH. Muhammad Kholil Bangkalan dalam kitab AsSilah fi Bayaani Nikah: ${ }^{30}$

1. Calon suami:

a) Laki-laki, jelas orangnya (bukan khunsa musykil).

b) Tidak sedang ihram untuk haji dan umrah

c) Tidak akan menikahi perempuan yang diharamkan

d) Tidak sedang memiliki 4 orang istri

e) Hendaknya memiliki kemampuan untuk memberi mahar, nafkah, pakaian dan tempat tinggal.

2. Calon Istri

\footnotetext{
${ }^{29}$ Lathifah Munawaroh, Tes Kesehatan Sebagai Syarat Pra Nikah (Studi UU Pernikahan di Kuwait), Yudisia : Jurnal Pemikiran Hukum Dan Hukum Islam, Volume 10, Nomor 1, Juni 2019, hlm. 114.

${ }^{30}$ KH. Muhammad Kholil Ibn Lathif al-Bangkalan, As-Silah fi Bayaani Nikah, Maktabah Tahmil, tahun 2021
} 
a) Perempuan,

b) Dapat dimintai persetujuannya

c) Tidak sedang melakukan ihram untuk haji dan umrah.

d) Tidak sedang dalam ikatan pernikahan atau masa idah (masa tunggu setelah talak/perceraian)

e) Tidak menjadi salah satu perempuan yang diharamkan dinikahi sebab nasab, saudara sepersusuan, dan sebab ikatan pernikahan seperti ibu tiri, menantu perempuan, mertua perempuan.

Dalam kalimat sebagai syarat menikah bagi calon suami nomor lima bagian

akhir menurut KH. Muhammad Kholil Bangkalan terdapat kalimat

maknanya rumah tempat tinggal yang tenang. Inilah syarat tambahan yang menurut penulis sangat penting dalam membangun rumah tangga yang harmonis setelah akad nikah. Sebagaimana pesan Alloh SWT dalam al-Qur'an sura Ar-Rum $30: 21$

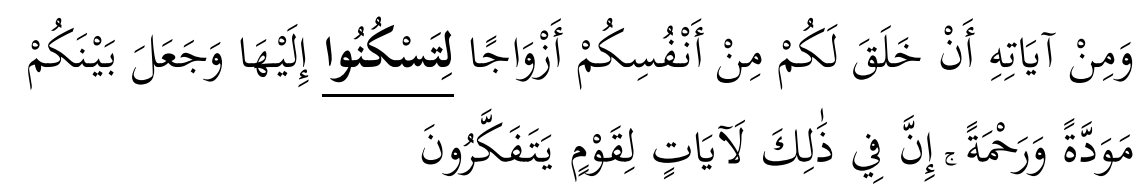

Artinya: Dan diantara tanda-tanda kekuasaan Alloh SWT adalah menjadikan bagi kamu sekalian pasangan hidup dari jenismu, agar kamu merasa tenang hatimu dengannya, dan dijadikan kebahagiaan dengan kasih sayang diantara pasangan suami-istri. Sebenarnya dalam pernikahan terdapat petunjuk bagi orang-orang yang berfikir. 
Jurnal DinamikA

Volume 2 No. 2 (2021)

E-ISSN: $2723-1410$

Website: https://jurnal.iainsalatiga.ac.id/index.php/dinamika/index

Dalam Bahasa Arab, ada empat kata yang semuanya bisa berarti "rumah",

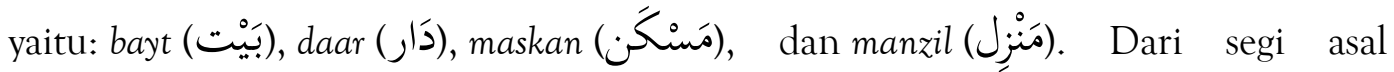

katanya, setiap kata tersebut memiliki makna dan nuansa tersendiri.

1. bayt (بَيْت berasal dari fi'il (kata kerja) baata/yabiitu (بَاتَّ/يَبْيْن )

yang artinya: bermalam,

2. daar (دَار) berasal dari fi'il daara/yaduuru (دَرَ/يَدُوُْرُ) yang artinya:

berkeliling, beredar,

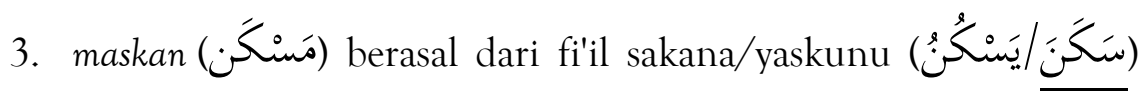

yang artinya: tetap, tenang,

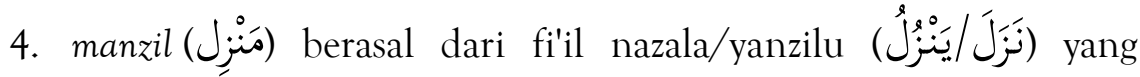
artinya: turun, singgah.

Maka dari keempat kata tersebut, semuanya telah mewakili empat fungsi rumah dan cara orang menyikapi dan menggunakan rumah:

1. Bayt, memiliki makna rumah sebagai tempat bermalam,

2. Daar, rumah sebagai tempat berkeliling atau beraktifitas,

3. Maskan, rumah sebagai tempat tinggal atau tempat menetap dengan tenang 
Jurnal DinamikA

Volume 2 No. 2 (2021)

E-ISSN: $2723-1410$

Website: https://jurnal.iainsalatiga.ac.id/index.php/dinamika/index

4. Manzil, rumah sebagai tempat mampir atau persinggahan

\section{Kesimpulan}

Pendidikan nikah menurut KH Muhammad Kholil Bangkalan adalah sebagai berikut :

1. Disampaikan dengan metode tanya-jawab praktis dan perlu dimasukkan dalam kurikulum pada pendidikan dasar dan menengah terlebih saat Pembelajaran Jarak Jauh berbasis internet online.

2. Pernikahan akan lebih harmonis apabila calon suami dan istri memiliki syarat yang diwajibkan dalam pernikahan termasuk syarat tambahannya, yaitu meliputi sertifikat vaksin, tes bebas covid-19 dan juga sangat baik apabila calon pasangan telah memiliki maskan atau rumah tempat tinggal guna membangun rumah tangga yang tenang dan bahagia

\section{Daftar Pustaka}

Al-Maraghi, Ahmad Mustafa. (1993). Terjemah Tafsir al-Maraghi. Semarang: Toha Putra.

al-Rahman al-Jaziri, Abd. (2003). al-Figh 'ala al-Madhahib al-Arba'ah. Bairut: Dar alKutub al-Ilmiah.

Amin, A. Rifqi. (2014). Sistem Pembelajaran Pendidikan Agama Islam pada Perguruan Tinggi Umum. Yogyakarta: Deepublish.

Amin, A. Rifqi. (2015) Pengembangan Pendidikan Agama Islam: Reinterpretasi Berbasis Interdisipliner. Yogyakarta: LKiS.

Arikunto, Suharsimi. (2006). Prosedur Penelitian Suatu Pendekatan Praktik. Jakarta: Bumi Aksara.

Bisri, Adib dan AF, Munawir. (1999). Kamus Arab-Indonesia al-Bisri, surabaya : Pustaka Progresif.

Departemen Agama RI, (2011). Al-Qur'an dan Terjemahannya, Jakarta : Cahaya Qur'an.

Departemen Pendidikan Nasional. (2003). Undang-Undang Republik Indonesia (UU RI) Nomor 20 tahun 2003 Tentang Sistem Pendidikan Nasional. Jakarta: Depdiknas. 
Jurnal DinamikA

Volume 2 No. 2 (2021)

E-ISSN: 2723-1410

Website: https://jurnal.iainsalatiga.ac.id/index.php/dinamika/index

Echols, John M. dan Hassan Shadily, (2013). Kamus Inggris-Indonesia. Jakarta: Gramedia.

Efendi, Agus. (2005). Revolusi Kecerdasan Abad 21: Kritik MI, EI, SQ, AQ E Successful Intelligence Atas IQ. Bandung: Alfabeta.

Fathoni, Muhammad Kholid. (2005). Pendidikan Islam dan Pendidikan Nasional [Pardigma Baru]. Jakarta: Depag RI Dirjen Kelembagaan Agama Islam.

Fathuddin, Syukri. (2008). Pendidikan Islam," dalam Din al-Islam: Pendidikan Agama Islam di Perguruan Tinggi Umum, ed. Yudiati Rahman. Yogyakarta: UNY Press.

Goleman, Daniel. (1999). Kecerdasan Emosional, dalam Emotional Intelligence ed. T. Hermaya. Jakarta: Gramedia Pustaka Utama.

Husain Al-Hamid, Zaid. (2001). Kamus Al-Mufid, Jakarta : Pustaka Amani.

Kamus Besar Bahasa Indonesia Luar Jaringan (Luring), (2014). KBBI Offline Versi 1.5, http://kbbi-offline.googlecode.com/files/kbbi-offline-1.5.zip.

Kartini Kartono, Kartini. (1998). Pengantar Metodologi Research, Alumni : Bandung.

Kholil Bangkalan, Muhammad. (2021), As-Silah fi Bayaani Nikah: Maktabah Tahmil

Moleong, Lexy J.. (2007). Metodologi Penelitian Kualitatif. Bandung: Remaja Rosdakarya.

Peraturan Pemerintah Republik Indonesia Nomor 55 Tahun 2007 Tentang Pendidikan Agama dan Pendidikan Keagamaan, dalam http://riau.kemenag.go.id/file/dokumen/pp55tahun2007.pdf,

Salim Bahreisy, (2004) Terjemah Singkat Tafsir Ibnu Katsir. Surabaya : PT. Bina Ilmu.

Shihab, Quraish. (2021) Surat An-Nisa ayat 16, Tafsir Al-Misbah, dalam aplikasi Qur'an All in One versi 3.2.3 Tahun 2021

Sugiono, (2014). Metode Penelitian Pendidikan. Bandung : Alfabeta, 2014.

Sugiyono. (2007). Metode Penelitian Kuantitatif Kualitatif dan R Eु D. Bandung: Elfabeta.

Sukmadinata, dan Syaodih, Nana. (2009). Metode Penelitian Pendidikan. Bandung: Remaja Rosdakarya.

Suwaid, Muhammad, (2003). Mendidik Anak Bersama Nabi Saw, Panduan Lengkap Pendidikan anak disertai Teladan Kehidupan Para Salaf, Solo : Remaja Rosdakarya.

Thobroni, M. (2015). Belajar dan Pembelajaran. Yogyakarta : Ar-Ruzz Media.

Tohet, Moh. (2021). Modernisasi Pendidikan Islam (Telaah Pemikiran Fazlur Rahman), dari https://ejournal.unuja.ac.id/index.php/edureligia/index.

Undang-undang Dasar Negara Republik Indonesia Tahun 1945, dalam http://www.dpr.go.id/id/uu-dan-ruu/uud45.

Undang-Undang No. 1 Tahun 1974 Tentang Perkawinan Pasal 1

Undang-undang No. 16 Tahun 2019 Perubahan atas Undang-undang Nomor 1 Tahun 1974 tentang Perkawinan.

Undang-Undang Republik Indonesia, No 20 Tahun 2003 Tentang Sistem Pendidikan Nasional

Zuchdi, D. (2009). Humanisasi Pendidikan: Menemukan Kembali Pendidikan yang Manusiawi. Jakarta: Bumi Aksara. 
Jurnal DinamikA

Volume 2 No. 2 (2021)

E-ISSN: 2723-1410

Website: https://jurnal.iainsalatiga.ac.id/index.php/dinamika/index

Okun, Barbara F. (1984). Marriage and Family Counseling. Boston: Northeastern University.

Ramulyo, Mohd. Idris. (1996). Hukum Perkawinan Islam Suatu Analisis Undang-Undang No. 1 Tahun 1974 Dan Komplikasi Hukum Islam. Jakarta: Bumi Aksara.

Sabiq, Sayyid. (1980). Fikih Sunnah Jilid 6. Bandung: PT. Al-Ma'arif.

Shihab, M. Quraish. (2008). Tafsir al-Mishbah. Vol. 1 - 15. Jakarta: Lentera Hati.

Sutoyo, Anwar. (2013). Bimbingan Konseling Islami: Teori dan Praktik. Yogyakarta: Pustaka Pelajar.

Thalib, M. (1996). Analisa Wanita Dalam Bimbingan Islam. Surabaya: al-Ikhlas.

Willis, Sofyan A. (2008). Konseling Keluarga. Bandung: Alfabeta

Jurnal:

Anindhita Maharrani, Anindhita, (2021), Perceraian di Indonesia terus meningkat, (diakses pada tanggal 5 Agustus 2021 dari https://lokadata.id/artikel)

Astriana, Nana. (2017). Pendidikan Seks Dalam Proses Pembelajaran (Studi Deksriptif Pada Guru Di Sma Negeri 2 Makassar), Jurnal Sosialisasi Pendidikan Sosiologi-FIS UNM.

Basit, Abdul. (2016). Bimbingan Perkawinan dalam Perspektif Al- Qur'an, Bimbingan Religi: Jurnal Bimbingan Islam, Vol. 7, No. 2.

Munawaroh, Lathifah (2019). Tes Kesehatan Sebagai Syarat Pra Nikah (Studi UU Pernikahan di Kuwait), Yudisia : Jurnal Pemikiran Hukum Dan Hukum Islam, Volume 10, Nomor 1.

Nasution, Khoiruddin. (2016). Perlindungan Terhadap Anak Dalam Hukum Keluarga Islam Indonesia, Al-Adalah Vol. XIII, No. 1

Reny Puspitasari, Johan dan Satiningsih. (2014), Perbedaan Penyesuaian Pernikahan pada Pasangan yang Menikah Muda, Jurnal Psikologi Teori dan Terapan 2014, Vol. 5, No. 1.

Rifiani, Dwi. (2011). Pernikahan Dini dalam Perspektif Hukum Islam. De Jure, Jurnal Syariah dan Hukum, Volume 3 Nomor 2.

Saidiyah, Satih, Julianto, Very. (2016). Problem Pernikahan Dan Strategi Penyelesaiannya: Studi Kasus Pada Pasangan Suami Istri Dengan Usia Perkawinan Di Bawah Sepuluh Tahun, Jurnal Psikologi Undip Vol.15, No.2.

Syahraeni, Andi. (2017). Nikah Dalam Perspektif Al Qur'an, Jurnal Al hikmah Vol. XIX No.2.

Tohet, Moh. (2021). Modernisasi Pendidikan Islam (Telaah Pemikiran Fazlur Rahman), dari https://ejournal.unuja.ac.id/index.php/edureligia/index.

Okun, Barbara F. (1984). Marriage and Family Counseling. Boston: Northeastern University.

Reny Puspitasari, Johan dan Satiningsih. (2014), Perbedaan Penyesuaian Pernikahan pada Pasangan yang Menikah Muda, Jurnal Psikologi Teori dan Terapan 2014, Vol. 5, No. 1.

Rifiani, Dwi. (2011). Pernikahan Dini dalam Perspektif Hukum Islam. De Jure, Jurnal Syariah dan Hukum, Volume 3 Nomor 2. 
Jurnal DinamikA

Volume 2 No. 2 (2021)

E-ISSN: $2723-1410$

Website: https://jurnal.iainsalatiga.ac.id/index.php/dinamika/index

Anna garlin Spencer. (2015). Problem of Marriage and Divorce, International Journal of Ethics

Happy Karlina Marjo \& Astri Kamasitoh, (2014). Jurnal Konseling dan Pendidikan, Jurnal.Konselingindonesia.Com, Volume 2 Nomor 2.

Jaafar-Mohammad, Imani and Lehmann, Charlie (2011) "Women's Rights in Islam Regarding Marriage and Divorce," Journal of Law and Practice: Vol. 4, Article 3.

Saidatur Rohmah. (2021). Batas Usia Menikah Dalam Perspektif Hukum Islam dan Hukum di Indonesia, Tahkim Vol. XVII, No. 1

Judiasih, Sonny D.; Rubiati, Betty; Yuanitasari, Deviana; Salim, Elycia F.; and Safira, Levana (2020). Efforts to Eradicate Child Marriage Practices in Indonesia: Towards Sustainable Development Goals. Journal of International Women's Studies, 21(6).

Day, Cathy, 2013. Marriage, Cambridge Scholars Publishing, Newcastle upon Tyne.

Meraj, Ahmad Meraj. (2018). The Importance Of Marriage In Islam. International Journal of Research-Granthaalayah, 6(11), $1-6$. https://doi.org/10.29121/granthaalayah.v6.i11.2018.1082

Digital Library Syamela versi 371

Lidwa Pusaka i-Software

Al-Qur'an All in One Versi 3.2.3 tahun 2021 